\title{
Artelogie
}

Recherche sur les arts, le patrimoine et la littérature de l'Amérique latine

2 | 2012

Mexique : espace urbain et résistances artistiques et littéraires face à la « ville générique »

\section{Sobrevivir con la Muerte: ecología de una práctica "pagana" en el valle de México}

Silvia Mancini

\section{OpenEdition}

Journals

Edición electrónica

URL: https://journals.openedition.org/artelogie/7648

DOI: $10.4000 /$ artelogie. 7648

ISSN: 2115-6395

Editor

Association ESCAL

Referencia electrónica

Silvia Mancini, «Sobrevivir con la Muerte: ecología de una práctica "pagana" en el valle de México», Artelogie [En línea], 2 | 2012, Publicado el 21 enero 2012, consultado el 07 enero 2022. URL: http:// journals.openedition.org/artelogie/7648; DOI: https://doi.org/10.4000/artelogie.7648

Este documento fue generado automáticamente el 7 enero 2022.

Association ESCAL 


\title{
Sobrevivir con la Muerte: ecología de una práctica "pagana" en el valle de México
}

\author{
Silvia Mancini
}

Su rostro está teñido de rojo, Su tocado de papel puesto en la cabeza, Su collar de jade. Tiene puesta su camisa con flores acuáticas,

Su falda con flores acuáticas. En su piernas campanillas y cascabeles, Sus sandalias de princesa. $\mathrm{Su}$ escudo con el signo de la flor del sol, En su mano tiene un manojo (de mazorcas) (Informante anónimo de Bernardino De Sahagún, en Miguel León-Portilla, 1958: 121) Más vale vestir santos que desvestir borrachos

(Expresión popular mexicana) 


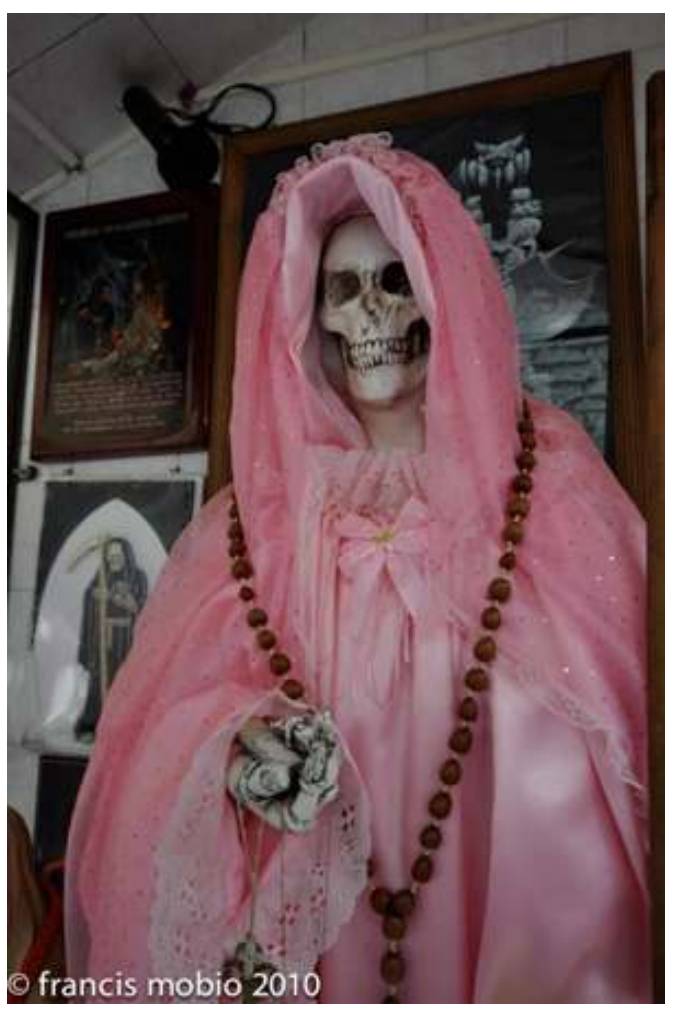

(c) francis mobio 2010

\section{Prólogo}

1 Los altares urbanos y periurbanos de la Santa Muerte, cuyo culto prolifera en las franjas desheredadas de la población que ocupa los barrios más degradados de México, ofrecen al transúnte un espectáculo poderoso y fascinante. Cuando uno se pasea por la ciudad y se cruza con un altar de la Flaquita, ${ }^{1}$ la mirada es impactada por el enmarañamiento barroco de imágenes de santos, objetos kitsch, reproducciones en formato reducido que, en una especie de abismo vertiginoso, refractan hasta el infinito la silueta de la estatua en "gran formato", que reina en el centro del altar, engalanada con vestimentas suntuosas. Estas estatuillas representan la "Santa de Siete Potencias" (vestida con los siete colores asociados a las esferas de influencia sobre las que la Santa es capaz de intervenir), la "Santa Piadosa" (representada sentada y que, como la piedad de Miguel Ángel, sostiene en sus brazos al hijo muerto), "El Jefe" (que representa a la Santa Muerte sentada sobre un trono, encarnando la función real sobre el mundo), diferentes "avatares" de esta entidad que veneran muchos chilangos ${ }^{2}$. Expuesta en altares al aire libre o encerrada en una urna de vidrio, vestida en forma diferente según la época del año y las celebraciones de que forma parte, la efigie del gran esqueleto, engalanado a

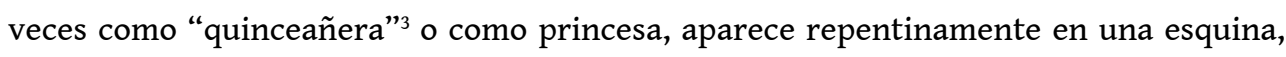
en algunos cruces muy frecuentados del Centro Histórico, en refugios protegidos ubicados en el corazón de los mercados populares, en el patio ruidoso de un edificio, en un garage arreglado cuidadosamente para rendirle honores.

2 ¿Desde dónde pueden captar el historiador de las religiones y el antropólogo esta forma de devoción que, desde los años 2000, ha dado tanto que hablar en los medios de comunicación? ¿Cómo analizar el culto de la Santa Muerte, de la que hasta ahora sólo se 
han explorado sus posibles raíces históricas o las implicancias sociológicas? ¿Qué otras lecturas son posibles de esta devoción, que convoca a tantos adeptos, en su mayor parte pequeños vendedores ambulantes que viven al día, hombres y mujeres surgidos del mundo obrero o artesano, o que están vinculados a medios carcelarios, delictivos, del narcotráfico o de la prostitución?

Si la naturaleza de toda institución simbólica es la de un artefacto a la vez real, social y discursivo (Latour 2009, 66), solamente un enfoque constructivista de este culto está en condiciones de rendir cuenta de la ecología de esta práctica popular urbana de México. La comprensión de este culto implica, en efecto, tomar en cuenta la co-emergencia y la co-evolución de las relaciones entre el culto mismo y el proceso de desarrollo y de poblamiento del Distrito Federal, proceso que consiste en modificar progresivamente el ecosistema lacustre de la región para poder recibir allí las diferentes olas migratorias. En el Valle de México, el culto de la Santa Muerte constituye sólo uno de los numerosos aspectos de la llamada "religiosidad popular", muy abigarrada en este caso, en un país como México al que el mismo Estado, con su retórica, contribuye a "folklorizar". Tan extraño a los horizontes teológicos del catolicismo oficial como a los de los movimientos evangélicos y pentecostales que pregonan la "teología de la prosperidad" -y que están afluyendo en México al igual que en el resto de América Latina-, la devoción por la Flaquita se inscribe además en una práctica de la existencia muy alejada de la de los movimientos neoindígenas y neonativistas que se disputan el protagonismo en las diversas expresiones de la New Age local. El perfil sociológico de los adeptos, su manera de inscribir su presencia en el territorio, las prácticas rituales que se derivan, hacen de los devotos un mundo a parte. Así, mientras un verdadero comercio de objetos de culto relativos a la Santa Muerte prospera en el valle de la ciudad de México, el culto mismo permanece instalado por fuera de los circuitos comerciales de creación y difusión de objetos, vestidos, publicaciones que emplean las imágenes de cráneos y de esqueletos. En México, estas imágenes prosperan en el seno de grupos neogóticos y punks, y fueron también recuperadas de manera "folklorizante" en la tradicional fiesta de muertos celebrada en el mes de noviembre en numerosas provincias del país. En los márgenes de la ciudad de México, cerca de los barrios burgueses y pequeñoburgueses habitados por buenos católicos o celosos evangélicos, pero también por una juventud portadora de una contra-cultura comercial, el culto de la Santa Muerte une a los portavoces de un mundo en guerra contra la muerte misma, la precariedad y el hambre, el desempleo crónico, la pobreza y la enfermedad que rondan esos barrios. Verdadera forma de resistencia frente a los males de un capitalismo agresivo y difuso engendrado por la política oficial del Estado, esta forma de culto vehiculiza una lógica simbólica precisa, la misma que organiza, en los antiguos politeísmos, las relaciones entre los humanos y los no humanos, lógica dotada de un intenso poder autorreparador y constructivo. 
Altar cerca del campamento de Martin Carrera

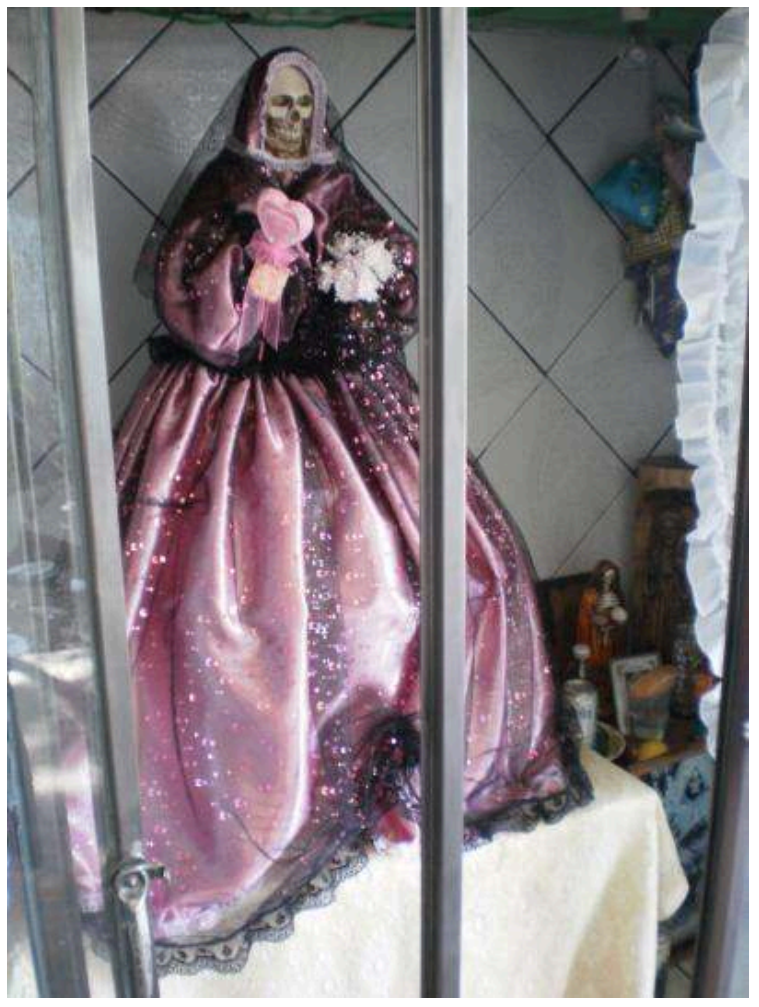

\section{1. "Como si..." la vida fuera la Muerte, o la ficción estratégica del ritual}

¿Qué representan estas esculturas de la Santa Muerte, vestidas cuidadosamente por costureras especializadas, y a las hay que dirigirse en ocasión de un pedido particular, durante el recitado mensual de rosarios, junto a los altares? ¿Por qué se le implora a ella para obtener el rápido fin del encarcelamiento de un familiar o de un amigo, o una protección poderosa en vísperas de una empresa riesgosa? ¿Por qué es a ella que algunos agradecen ofreciéndole un concierto de mariachis, un espectáculo de danzantes, flores y velas, cigarrillos de marihuana, muñecos de peluche o frutas? La observación atenta de la vida cotidiana de los devotos de la Santa Muerte permite que surjan algunos elementos de respuesta, pero teniendo en cuenta dos condiciones: primero, reconocer la existencia de una continuidad casi morfológica entre medio ambiente urbano, entendido como "biotopo" específico, y conductas simbólicas de los adeptos al culto; luego, leer las relaciones entre la Santa y sus devotos en comparación con las lógicas y los modos operatorios de todo politeísmo: la devoción que analizamos da cuenta de esas relaciones de culto entre humanos y no humanos que los misioneros de los siglos XVI y XVII designaban con los términos "idolatría" o "paganismo".

El proceso de poblamiento que, a través de oleadas sucesivas, consistió en arrancar a la naturaleza las porciones de espacio que se desecaron, se deforestaron, invadidas inicialmente por construcciones en chapa y cartón-constituidas por una sola pieza, luego, una vez consolidadas, dotadas de varias piezas, a medida que estas nuevas colonias eran provistas de servicios-, constituye claramente el origen de la fisonomía actual del Distrito Federal. Desarraigadas de sus aldeas rurales, sometidas a una 
migración interna casi forzosa por las condiciones miserables de vida que distinguen al campo mexicano, estas poblaciones migrantes han luchado colonizando el hinterland de México. Esta lucha se ha dirigido hacia la humanización no solamente del territorio, sino también de la realidad ambiente en su totalidad, cuyos mecanismos quedaron fuera del alcance de estos actores de los "márgenes".

Detalle de un altar

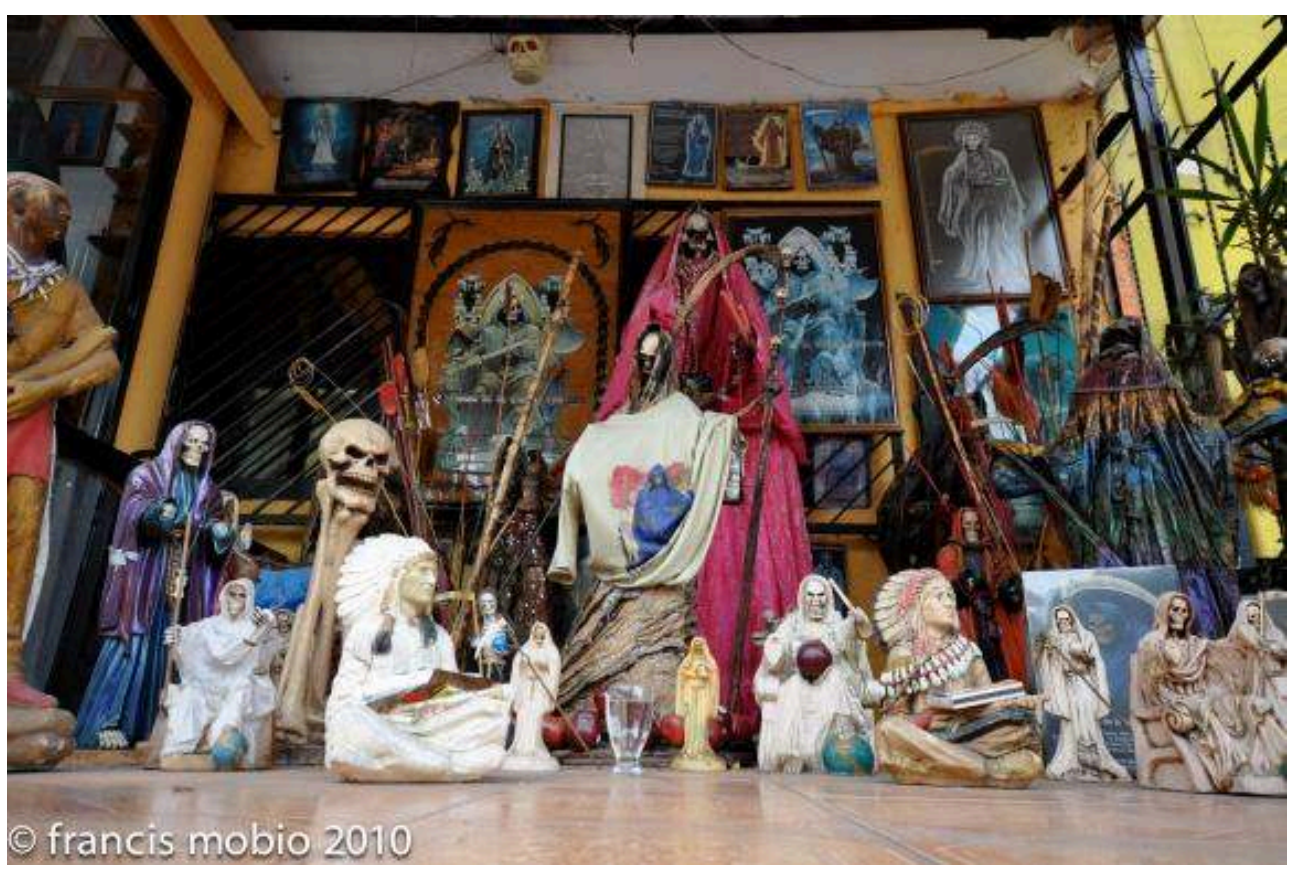

El culto de la Santa, muy vívido en este tipo de colonias construidas sobre las colinas deforestadas en la periferia de la ciudad, parece encarnar una de las posibles modalidades de humanización del territorio y de la incertidumbre que lo habita. Lejos de representar, como una lectura superficial podría hacer creer, una entidad amenazante que atormenta el imaginario de esas comarcas desheredadas, o la celebración de la violencia extrema con la cual coquetearía el mexicano, cargado con una pasión ancestral por el universo de la muerte, la Santa Muerte se presta a otra lectura. Personificación mítica no de una realidad precisa, sino más bien de una función, ella sería no tanto el símbolo o el significante de un concepto o de un objeto definido sino más bien un dispositivo operatorio, llamado a transformar la realidad para volverla susceptible de que sea vivida y habitada. La praxeología inherente a la Santa Muerte, así como su naturaleza de "dispositivo operatorio", son detectables en diversos niveles. Primero, esta figura cumple una función de atractivo, que totaliza y encarna, en sus diferentes rasgos esqueléticos, todos los aspectos de la realidad que los seres humanos no dominan (los azares, las diversas formas de negatividad, la incertidumbre, la enfermedad, la mala suerte, la prisión, la muerte misma). En tanto entidad mítica, la Santa ofrece así un rostro y un nombre a los imponderables de la existencia sin nombre y sin rostro. La "figuración" y la "personificación", en los que desemboca todo proceso mitopoiético, expresarían entonces, en un primer nivel, esta función de la Santa Muerte que es la humanización de lo "no-humano", es decir, el conjunto de los factores que resisten a la acción transformadora y ordenadora de los seres humanos. 
7 Esta función "humanizadora", sin embargo, no se limita a "significar" la parte no humana y amenazante de la existencia. La figuración de lo no humano no es más que la condición propedéutica para la instauración de una relación pragmática con eso no humano, en la medida en que, a través del culto, los devotos ponen en juego las condiciones de una negociación y de un comercio cotidianos con esta realidad no humana que excede su control. Prisioneros de un régimen de vida sin salida y con un trazado ya conocido, en la imposibilidad de conducir su existencia según una directiva "elegida" o "querida", y valiéndose del poder absoluto de la Santa sobre el mundo, los fieles mismos tienen acceso a la acción, a la actividad, a la potencia en su estado puro, todas dimensiones inalcanzables por otra vía. En definitiva, ella es el "mundo", en lo que éste tiene de negativo y de potencialidades prometedoras, mundo aprehendido en una forma personal para hacerlo susceptible de relación y de dirección. Es por eso que ella constituye un vector esencial en el proceso de cosmicisación-humanización de la existencia, lo cual va de la mano con el proceso de urbanización que consistió en transformar el espacio deforestado, resecado, contaminado, localizado al margen de la ciudad, en un "mundo habitable".

8 Detrás de la silueta esquelética venerada, se pueden reconocer algunos rasgos comunes a las figuras míticas, de las cuales se puede decir, en las civilizaciones no monoteístas tanto antiguas como modernas, que ellas son, de alguna manera, tal o cual aspecto del mundo sobre el cual los hombres, a través de este "rodeo", buscan ejercer su control, pues efectivamente no dominan ni la enfermedad, ni la muerte, ni la esterilidad, ni la miseria, ni la precariedad, en suma, todo lo que es incierto en la existencia del hombre histórico.

Por eso conviene abordar estas entidades míticas calificadas como "paganas" o "ídolos" menos como "seres" verdaderos que como operadores o funciones representadas bajo una forma personal. Con realidades que se le asemejan, es decir "personales", el hombre puede en efecto establecer relaciones e intercambios. Pero los politeísmos no se limitan a una personificación del mundo con el cual desea entrar en relación. Proceden también a una diferenciación de esas entidades personales, cada una de las cuales es definida por una esfera de acción que le es propia, que la distingue de todas las otras y la caracteriza, así como en México se ha hecho de la Santa Muerte algo distinto de las otras entidades veneradas: la Virgen de Guadalupe, Jesucristo, San Judas Tadeo, etcétera. La inmanencia, la personificación y la diferenciación de los dioses del paganismo no señalan, a ojos de sus devotos, un límite (como afirma el discurso teológico, cuando compara los límites de los dioses paganos a las prerrogativas del dios único, ilimitado, de los monoteísmos). Al contrario, son precisamente esta inmanencia, esta personificación y esta diferenciación las que le dan fuerza a los dioses paganos y los vuelven susceptibles de establecer una relación con los humanos. El culto (cuya etimología, del verbo latino colere, cultivar, reenvía precisamente a la vaga conciencia que tienen los mismos seres humanos de mantener en vida a las entidades no humanas, a través de la práctica ritual) aparece entonces como el medio por excelencia de negociación y de transacción, de diálogo y de presión sobre y con la alteridad no humana -en este caso, con esa parte de la existencia que resiste a nuestros esfuerzos por humanizar el mundo-. Así, extraños a todo determinismo, a toda noción de una voluntad divina exclusiva y absoluta, los paganismos le otorgan a los hombres, a través del culto, un margen más amplio de intervención sobre la realidad. 
Altar ubicado en el cruce del Centro Histórico entre la calle Moneda y la calle Academia

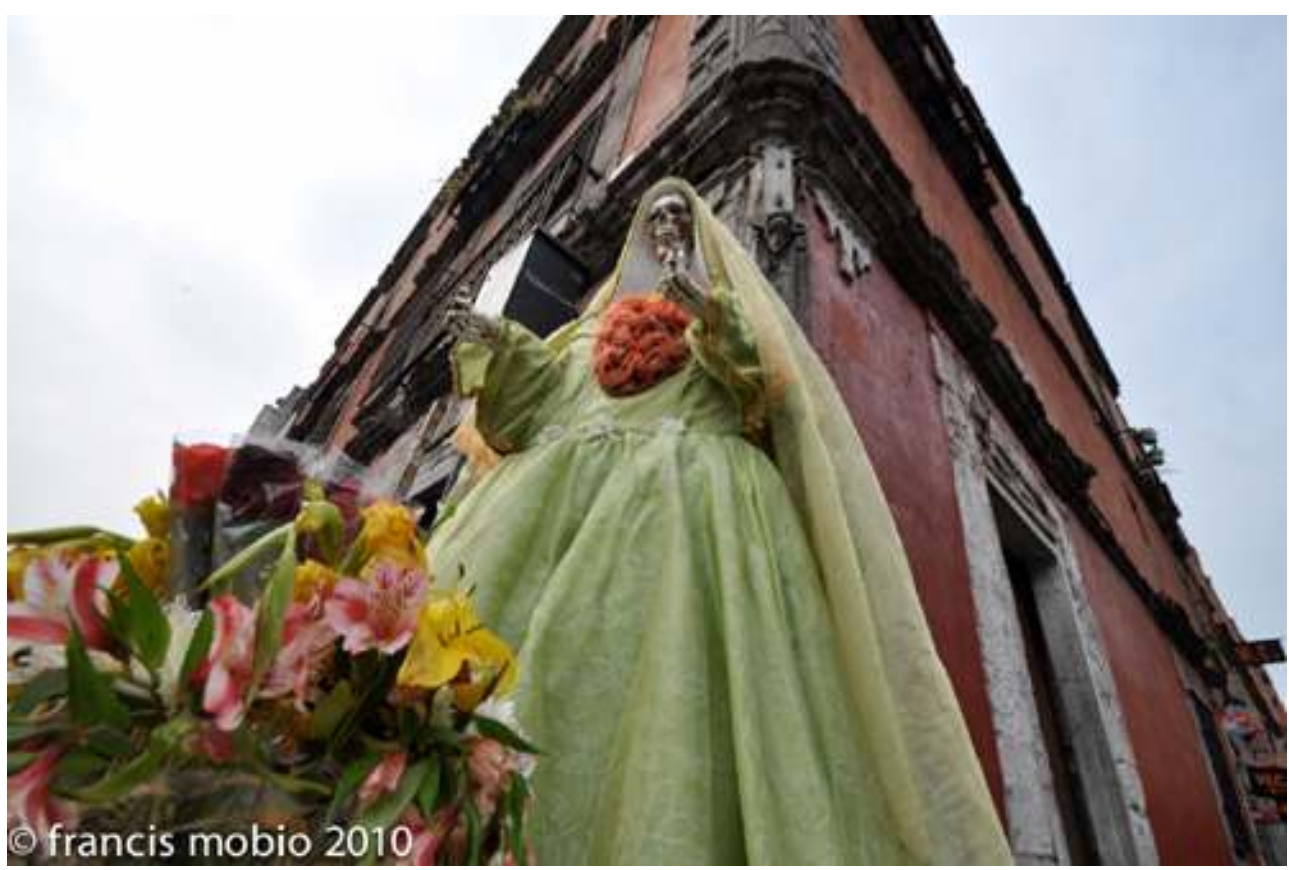

\section{La muerte en persona, o el doble doméstico}

10 La Santa no se reduce a un "significante" o a un "símbolo" de algo. El hecho de que encarne acabadamente una función operatoria en el marco de una ecología cultural específica, no se deriva solamente del aspecto "objetivo" de semejante ecología (la Santa en tanto figuración mítica del mundo, propedéutica para la acción sobre éste). Además del hecho de ser el vector de una práctica que tiene como objeto el mundo, ella es también el vector de una práctica ejercida sobre el sujeto, lo cual constituye el aspecto "subjetivo" de la relación entre ella y sus devotos. La intencionalidad activa que se le asigna a la Santa Muerte -ella come frutas, bebe tequila y pulque, fuma marihuana, se viste como una reina y, según su estado de ánimo, protege o abandona a los humanosforma una figura de "doble" de la intencionalidad humana. En este culto, semejante intencionalidad se ejerce y se expande a través de las hazañas de la Niña Blanca, que actualizan y tornan visibles los afectos, los temores y los deseos de los adeptos. La función de la Santa Muerte, en definitiva, no es exclusivamente la de personificar el mundo. Su función es también la de personificar el doble de sí mismo, y más precisamente esta parte desconocida de sí mismo que uno no llega a expresar ni a manifestar, pero que se expresa y se manifiesta sin embargo en los poderes atribuidos a su doble. Desde este punto de vista, es característico el tratamiento al que cada devoto somete a la escultura de la Santa que conserva en su casa, ubicada en el centro del altar hogareño. La Santa doméstica recibe un nombre, es ataviada según el gusto de su propietario, se le otorga tal o cual rasgo de carácter, se leen en su rostro los estados interiores que anuncian desgracias o éxitos. Por intermedio de esta Santa doméstica, proyección externalizada de ellos mismos, los devotos no solamente hablan de sí mismos, sino que intervienen sobre todo de manera autocorrectiva sobre sí mismos. El uso que algunos detenidos hacen de esas efigies nos ofrece un ejemplo típico de la praxeología desarrollada a su alrededor, e ilustra bien la naturaleza "autoconstructiva" de las relaciones que la vinculan a sus devotos. Después de haber esculpido la imagen en los 
talleres del Reno, ${ }^{4}$ la estatua es remitida por el prisionero a sus familiares para que la "curen" -es decir, someterla a un trabajo ritual (realizado por un curandero o una santera) destinado a acelerar la salida de prisión-. Asimismo, la práctica que consiste en llevar a su doble doméstico (la Santa), ataviada y adornada de manera solemne, al rosario público que se celebra junto a un altar urbano para que asista a la ceremonia en su honor y se beneficie con la bendición final, confirma esta dimensión de esa entidad como "prótesis" de sí mismo, consagrada a llegar a las zonas fuera del alcance de los hombres. La Santa se confunde con, o más bien ella deviene, el devoto mismo cuando, por ejemplo, sus fieles, durante situaciones de fuerte conflicto familiar o ante un peligro de muerte, afirman haber escuchado su voz saliendo de su propio cuerpo o hablándoles para darles consejos antes de externalizarse súbitamente bajo la forma de una aparición. La continuidad básica entre la Santa y sus devotos se expresa además a través del hecho de que éstos son casi todos, de alguna manera, "regresantes", objetos de milagros y devueltos a la vida luego de accidentes, heridas de armas de fuego, grescas cuyos estigmas corporales estos hombres y estas mujeres exhiben gustosos, estigmas que se funden y se confunden con los tatuajes que reproducen la imagen de su salvadora.

El cuerpo se transforma en soporte de identificación devocional con la Santa Muerte

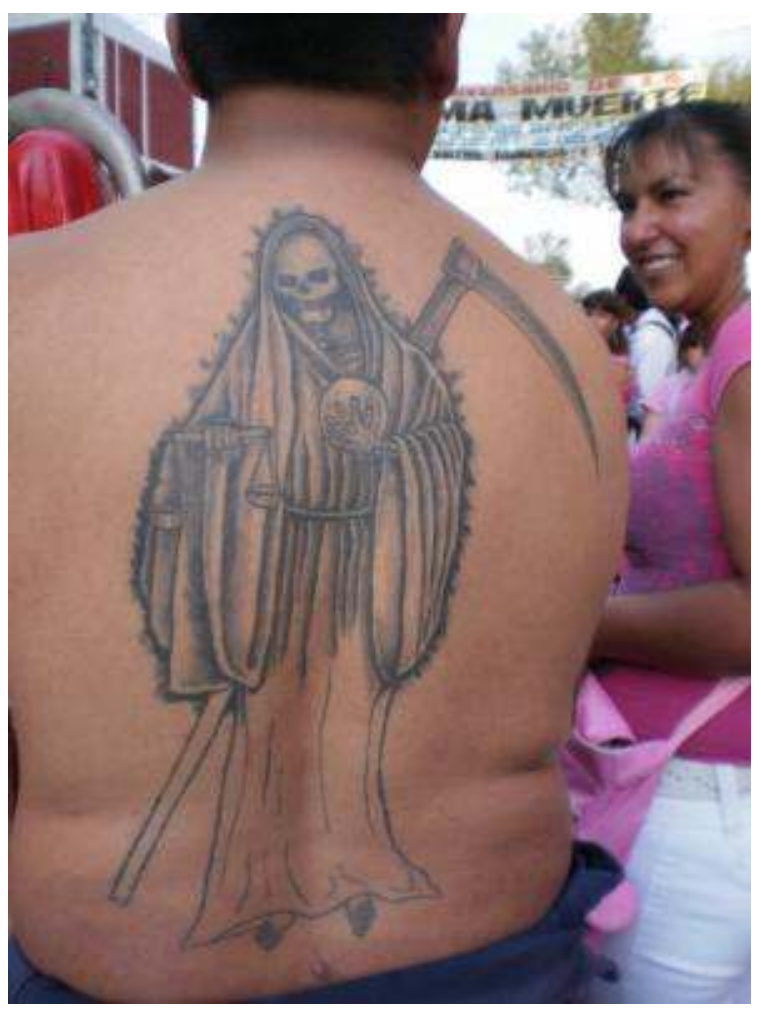


Costurera especializada en confecciones de vestidos para Santas Muertes, en su taller del Campamento de Lindavista

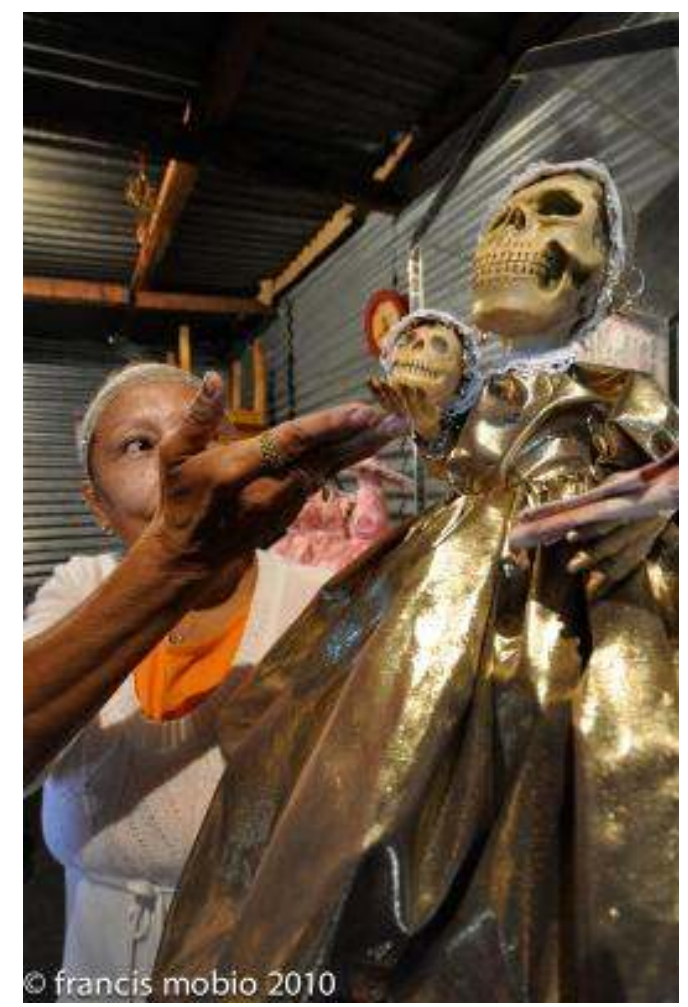

11 A partir de esto podemos mensurar la enorme distancia que separa a la Santa Muerte de la concepción de lo divino vehiculizada por los monoteísmos, que hacen de la trascendencia del dios su fundamento instituyente (Jan Assmann, 2007). En el caso del culto de la Santa Muerte, al contrario, es precisamente la naturaleza a la vez sagrada e inmanente de ésta lo que se impone en tanto expresión directa de los aspectos positivos y negativos del mundo, que es lo mismo que decir en tanto expresión directa de la vida. A través de la Santa es entonces la vida misma lo que se celebra. Esta unidad, paradójica a nuestros ojos, de inmanencia y de sacralidad de la función cultural de la Santa podría explicarse precisamente a través de la práctica ritual de su símbolo. En el marco de su culto, ya casi no opera como "representación" o significante de una realidad dada; su símbolo da cuenta menos del registro de la significación que de la "expresión". Se presenta como emanación directa y sensible de una realidad cuyos términos contiene y actualiza, prolonga real y fácticamente (y no metafóricamente). Más cercana a la noción nahua de ixiptla $a^{5}$ que a la de "imagen-representación" en el sentido occidental, esta imagen no es metáfora de otro mundo; en las prácticas que la enmarcan casi no se descubre la trascendencia, ni la salvación, ni la moral (a pesar de las plegarias que se le dirigen y que están calcadas sobre las de la liturgia católica). A semejanza de un conmutador activo que permite a la vez volver el mundo habitable y humanizarse a sí mismo frente al riesgo de la deshumanización cotidiana, ella ejerce la función de un atractivo poderoso (Serge Gruzinski, 1999: 274), capaz de reactivar sin cesar la acción sobre el mundo y sobre sí misma. 


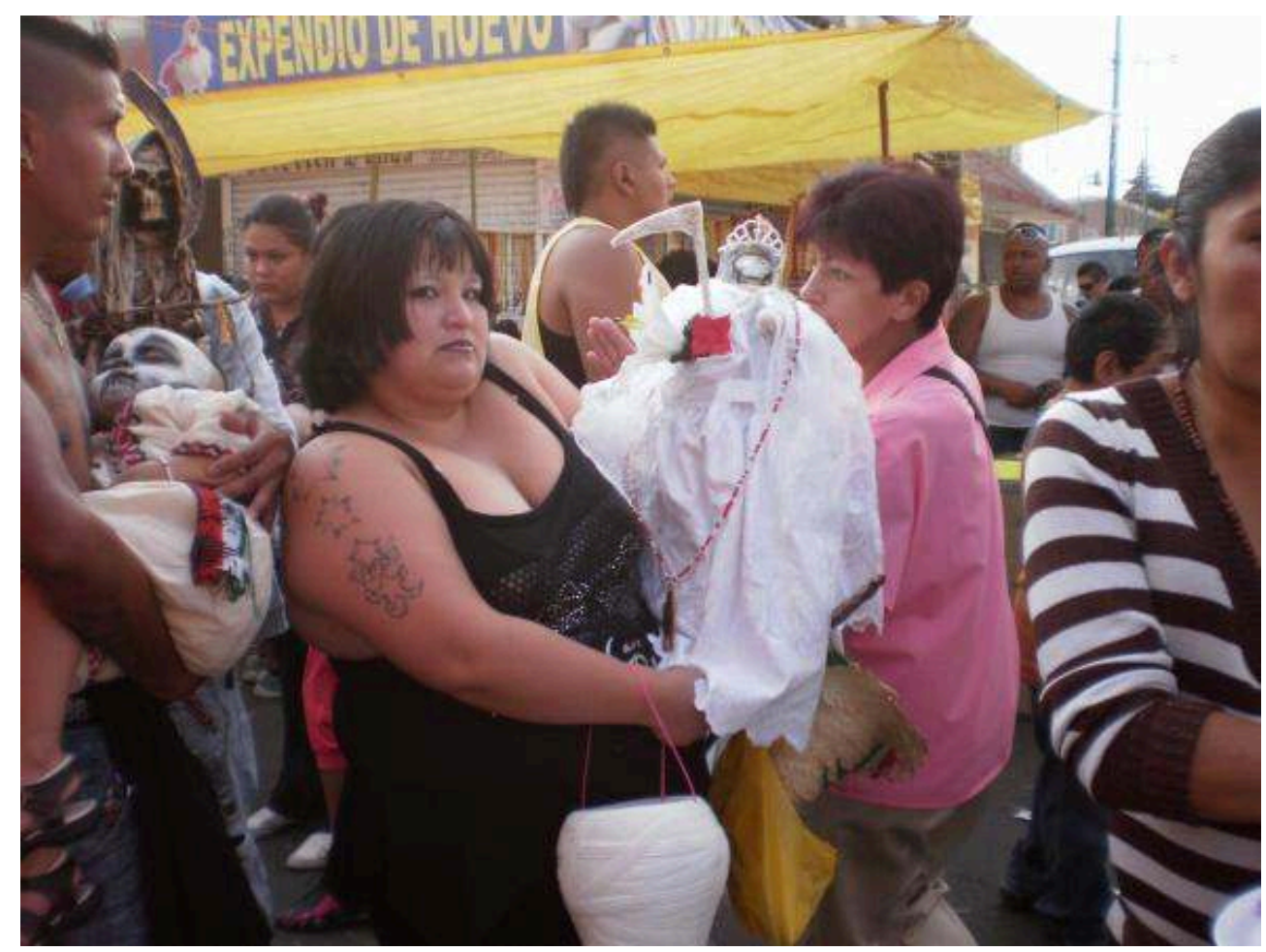

\section{Hábitos, imágenes sagradas y estados de sugestión en México}

12 En México, las prácticas devocionales populares que se desarrollan al margen de las formas religiosas oficiales se apoyan en comportamientos rituales que no remiten específicamente al culto de la Santa Muerte. Es el caso, por ejemplo, de la práctica que consiste en vestir la imagen de algunos santos protectores, a los que los fieles dedican un culto especial, pero es también el caso de la costumbre de celebrar el "aniversario" de ese santo, con una fiesta en su honor, marcada por el cambio de la vestimenta de la efigie. En el caso de la Santa Muerte, el aniversario de la imagen coincide con la inauguración de un nuevo altar, instalado por el dueño de éste, que se realiza tanto para honrar una promesa hecha en otro tiempo a la Santa (por ejemplo, superar una tóxico-dependencia, abandonar el narcotráfico o un grupo de malas compañías, renunciar a un consumo excesivo de alcohol o a un comportamiento de infidelidad conyugal), como para agradecer a la Santa por un favor recibido (así, haber escapado a la muerte por una enfermedad o un accidente, o haber podido burlar a un asesino a sueldo). La celebración del aniversario de una efigie, en tanto imagen eficaz, parece así renovar en ocasiones fijas, y en beneficio de los seres humanos, la actividad transformadora, correctiva y protectora que le está asociada.

La investigación comparativa consagrada a la práctica de vestir los santos, realizada en el Distrito Federal y en sus alrededores (estado de México), ha sacado a la luz convergencias y divergencias en el tratamiento ritual de las imágenes de culto. ${ }^{6} \mathrm{El}$ trabajo de campo, que se desarrolló en el otoño de 2010, alcanzó a tres figuras de santos, inscritas de diversa manera en el panteón local. Las dos primeras, el Niño Dios y San Judas Tadeo, forman parte del culto canónico aceptado por la Iglesia católica. La tercera, la Santa Muerte, objeto extracanónico, como ya dijimos, nunca será integrada 
en los marcos institucionales de la Iglesia, en razón de la incompatibilidad teológica básica entre la veneración de su imagen y el mensaje cristiano. Fundado en el principio escatológico de la Resurrección -que la iconografía oficial ilustra a través de la figura de la victoria definitiva de Cristo sobre la muerte-, fue precisamente la adopción de ese principio lo que condujo al cristianismo a romper de manera irreversible con el universo simbólico del paganismo antiguo, cuyos horizontes ideológicos prácticamente no ofrecían "esperanza" en una resurrección futura (De Martino, 1958).

Prendas de Santas exhibidas el día 1 ero de noviembre durante las celebraciones alrededor del altar de Tepito, en la calle Alfarería

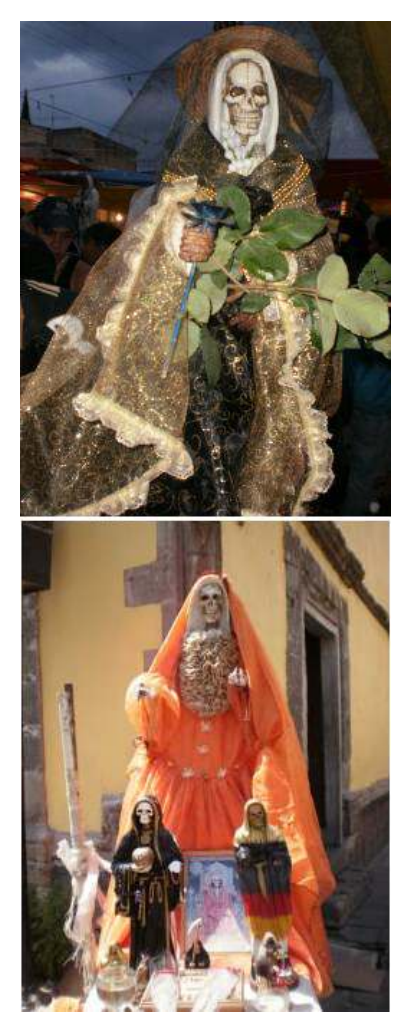


Prendas de Santas exhibidas el día 1 ero de noviembre durante las celebraciones alrededor del altar de Tepito, en la calle Alfarería

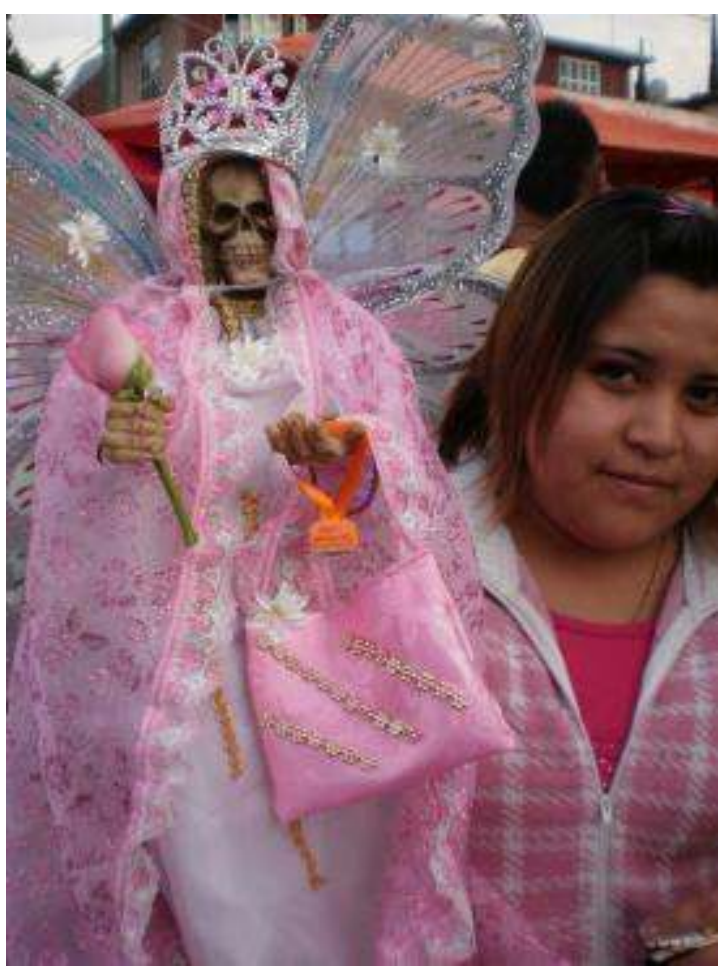

Altar del Centro Histórico

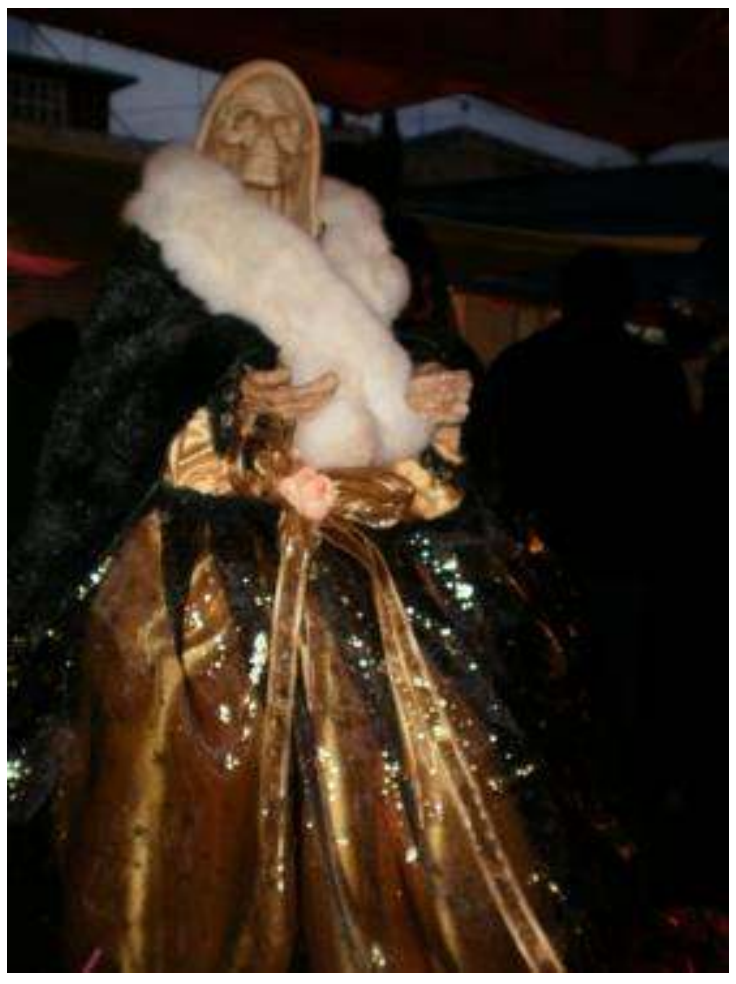

14 A pesar de la distancia teológica que separa al culto del Niño Dios y al de San Judas Tadeo del de la Santa Muerte, el tratamiento simbólico similar al que estos tres santos son sometidos incita al historiador de las religiones a asociarlos y, en consecuencia, a 
interrogarse sobre cuál es la frontera que, en México, separa las prácticas calificadas como "paganas" de las prácticas "ortodoxas". Las modalidades y la función cultural de la vestimenta de las efigies de estas tres figuras convergen en más de un punto. Primero, el hecho como tal de vestir los santos ilustra un mismo proceso, el de humanización-identificación y, a la vez, el de disociación funcional entre los devotos y su entidad protectora. Así, la costumbre perfectamente canónica de vestir al Niño Dios confirma la lectura hecha al tema del tratamiento al que está sometida la Santa Muerte, entendida como un doble de sí. La vestimenta de la imagen del Niño Dios también debe ser cambiada en ocasión de su aniversario; en ese caso, la humanización del Niño y su identificación con el dueño de la efigie adquieren una forma insólita: después del nacimiento (la compra de la imagen), el bebé Jesús es vestido como un recién nacido y se le ofrecen los peluches y los juguetes típicos del primer año de vida. Luego, cuando crece, la efigie será vestida como niño, luego como joven, antes de vestir los hábitos de un santo adulto, hábitos que no son otra cosa que los del avatar particular del Niño Dios, al que el dueño de la imagen decidió consagrar toda su devoción (Niño de las Palomas, Niño-Pa, Niño Cirujano, Niño Doctor, Niño del Sagrado Corazón, etcétera).

Exhibición de prendas del Niño Dios en la tienda especializada "Chela creaciones", ubicada entre la Merced y el Centro Histórico

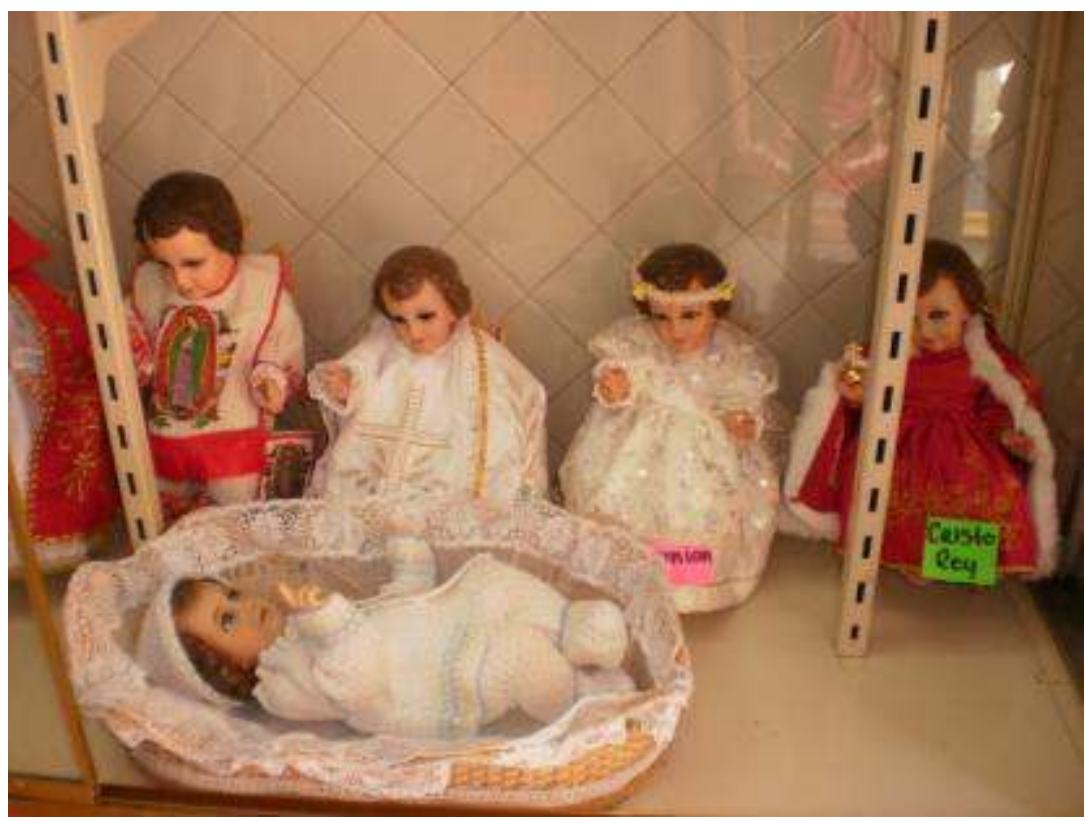


Detalle del Niño cirujano e imagen de los diferentes avatares del Niño Dios en una tienda especializada

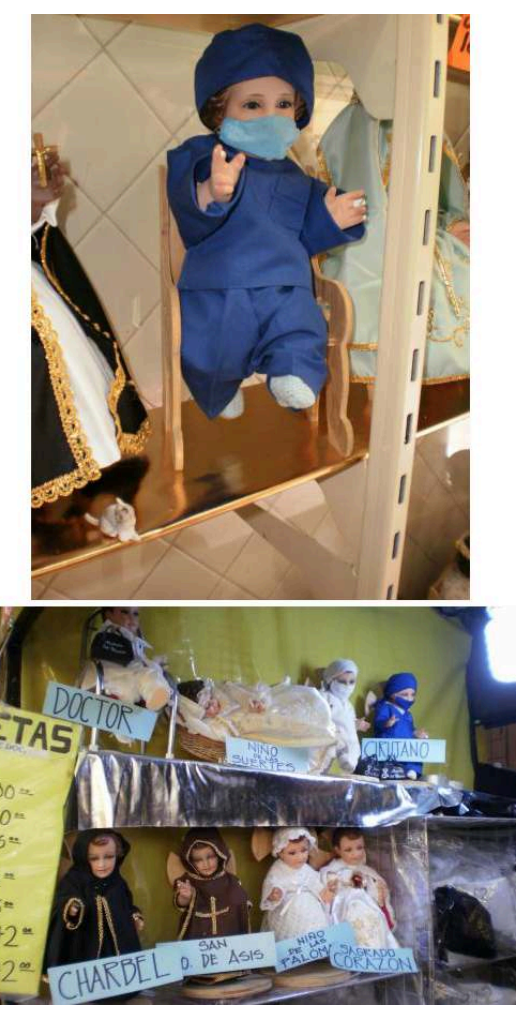

Durante las procesiones donde se celebra a ese santo popular del Distrito Federal que es San Judas Tadeo (santo que los chilangos veneran como santo "de las causas perdidas"), a menudo son los fieles mismos los que visten su hábito, para honrar una deuda de reconocimiento por un favor recibido; o bien visten a un hijo como San Judas, después de haberle "jurado" al santo realizar ese gesto en caso de obtención de un favor especial. ¿De dónde viene esa costumbre de vestir las imágenes del santo? ¿Por qué los hábitos que lo recubren y lo identifican tienen tanta importancia? 
Cada 28 de octubre, miles de fieles se congregan en el santuario dedicado a San Judas tadeo, ubicado en la esquina de avenidas Paseo de la Reforma y Zarco

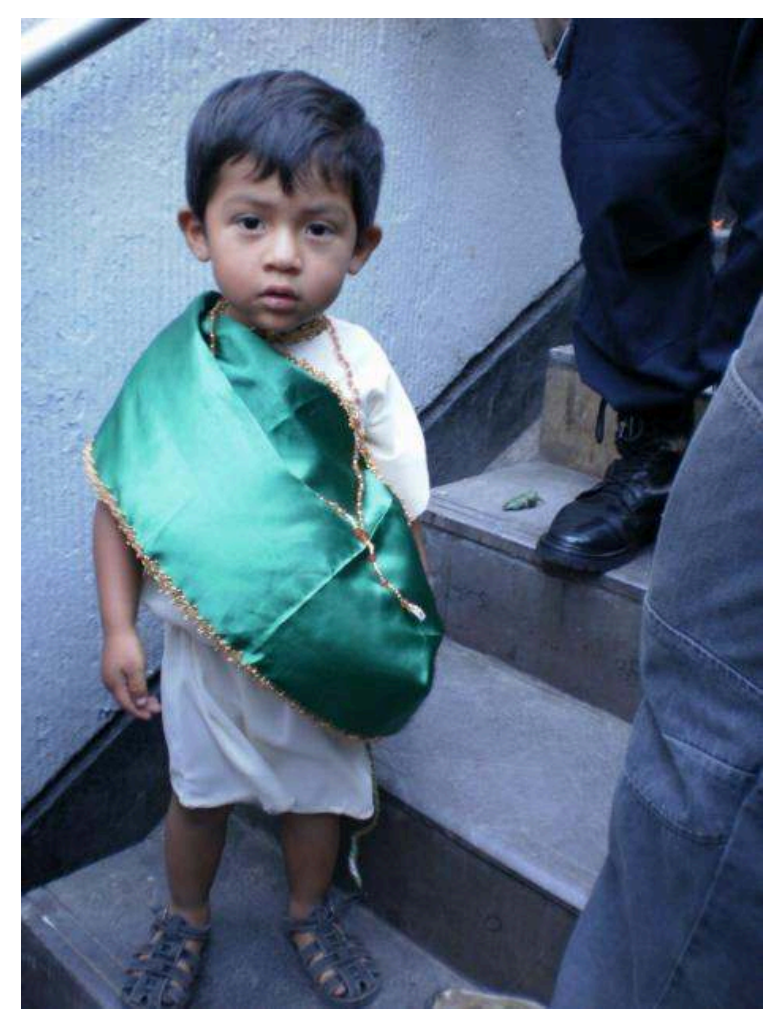

Quien observe de cerca la vida cotidiana que late en los barrios populares de México no puede quedar indiferente ante la importancia que se le asigna en esta ciudad al uniforme, a la vestimenta ceremonial o de trabajo, a la ropa de función y, más generalmente, a las marcas vestimentarias que indican el estatus, el oficio desempeñado, la pertenencia profesional a una corporación o a una institución escolar, e incluso el origen geográfico o étnico de los individuos. En el Centro Histórico, la presencia masiva de comercios consagrados a la venta de telas, artículos de mercería, accesorios, botones, ropa informal, sombreros, vestidos de gala y uniformes (combinados con una rica panoplia de elementos vestimentarios relacionados) se transforma en algo opresivo. La frecuentación de estos lugares permite descubrir que semejante producción textil y decorativa es empleada de manera indiferenciada para realizar los vestidos y los hábitos destinados tanto a los humanos como a las imágenes sagradas. En los barrios del centro o de la Merced, los escaparates de ropa de bautismo destinada a los recién nacidos, a los jóvenes, a la primera comunión, a los adolescentes, al matrimonio, se prolonga, sin solución de continuidad, en una profusión de prendas y de accesorios para las efigies del Niño Dios.

17 En los quioscos de diarios, las revistas especializadas en trabajos manuales utilizadas por las amas de casa y las costureras que realizan de manera artesanal trabajos de costura para ellas mismas y sus familias, publican regularmente números especiales con los moldes para confeccionar las vestimentas destinadas a los santos expuestos en las iglesias. 


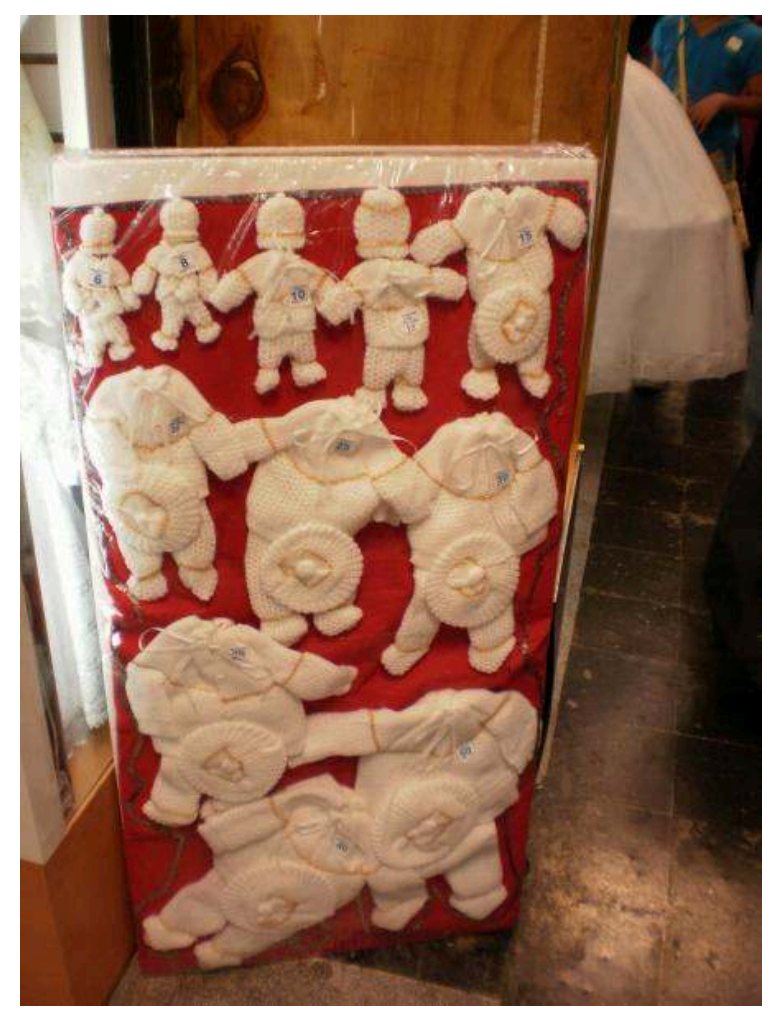

18 La actividad comercial que se ha desarrollado alrededor del atuendo de esta nueva entidad feminizada del panteón popular del Distrito Federal que es la Santa Muerte ofrece sorpresas suplementarias. La vestimenta de su imagen denota una preocupación de creatividad mucho mayor, pues la Santa se ha sustraído a los códigos vestimentarios de la iconografía oficial a la que sí están sometidas las imágenes canónicas. Quizá sea por ello que el dueño de una imagen de la Santa, independientemente del formato de ésta, no duda en rivalizar en originalidad y excentricidad con los otros devotos, eligiendo para "su" Santa atuendos espectaculares, como si se tratara de su propia vestimenta y como si, a través de ésta, estuviera en juego su propio prestigio. De alguna manera avatar de sí mismo, la imagen de la Niña Blanca exige no solamente atenciones constantes, sino también cuidados materiales y una escucha, ya que -según palabras de su dueño- la estatuilla manifiesta abiertamente sus preferencias tanto en vestimentas como en alimentos, las cuales, una vez satisfechas, le permitirán ejercer una mejor protección sobre su propietario. Concebidas, realizadas y valoradas (como nunca lo serán las ropas de los mismos devotos), luego cambiadas, lavadas y planchadas antes de usarlas de nuevo, las vestimentas que cubren a la Santa Muerte o al Niño Dios son, diríamos, indisociables del poder activo, transformador y resolutivo de las imágenes que las llevan. Artefactos humanos con rasgos humanos, encarnando bajo una forma externalizada el poder humano de autocorregirse y de entregarse de nuevo a la acción, la Santa Muerte, el Niño Dios y sus hábitos son una sola y misma cosa.

Esta pasión por las vestimentas, que produce asombro y ejerce un fuerte impacto estético, se observa en la consulta de revistas mexicanas de trabajos manuales. Éstas contienen los moldes y las instrucciones para la confección hogareña de vestimentas destinadas a todo tipo de objetos, ya se trate de seres animados o inanimados (desde animales hasta cubre-inodoros, desde el cuerpo de una quinceañera hasta un Niño Dios 
de yeso o de resina). Casi se podría decir que esos revestimientos, a menudo extravagantes, le otorgan a todos esos objetos heteróclitos un suplemento de sentido o una eficacia especial.

No hay que descartar que exista una relación entre la práctica de vestir los santos y el estatus atribuido a la visión y a las imágenes en la cultura mexicana, marcada en profundidad por el Barroco, que dio un fuerte poder instituyente a los efectos escenográficos y a la práctica de la "teatralización" de contenidos edificantes. De hecho, en México, en manos de los colonizadores, esos efectos y esos contenidos fueron poderosos vectores tanto de desculturización de las masas indígenas como de la apropiación simbólica de las realidades europeas (Gruzinski, 1990). Posiblemente ésta sea la razón por la que en México los dispositivos ortoprácticos que actúan en la cultura popular explotan de manera tan sistemática la apariencia vestimentaria y la fascinación alucinatoria que ella puede suscitar. Sin llegar a afirmar que existe una continuidad ininterrumpida entre el mundo prehispánico y la modernidad poscolonial, en México son muchos los que asocian todavía la vestimenta al poder activo inscrito en esos artefactos simbólicos que son las divinidades, o no importa qué otra entidad a la que se le asigna una eficacia no humana. A este respecto, son muy significativos los testimonios que se encuentran en los escritos de Bernardino de Sahagún, relativos a la costumbre prehispánica de identificar al dios a partir de sus ornamentos y características vestimentarias. También es significativo la costumbre, en poblaciones rurales de diversos estados de la República (situados entre la Sierra Madre oriental y occidental), de revestir ritualmente pequeñas imágenes de papel recortado o en piedra. Lavadas, vestidas, honradas, manejadas con todo cuidado -como si se tratara de agentes activos-, esas piedras y esos figurines son tratados como entidades capaces de proveer lluvias y buenas cosechas (Baez y Dehouve, 2010; Stresser-Pean, 2011). 
Santa con vestimentas suntuosas. Exhibida el día 1ero de noviembre durante las celebraciones alrededor del altar de Tepito

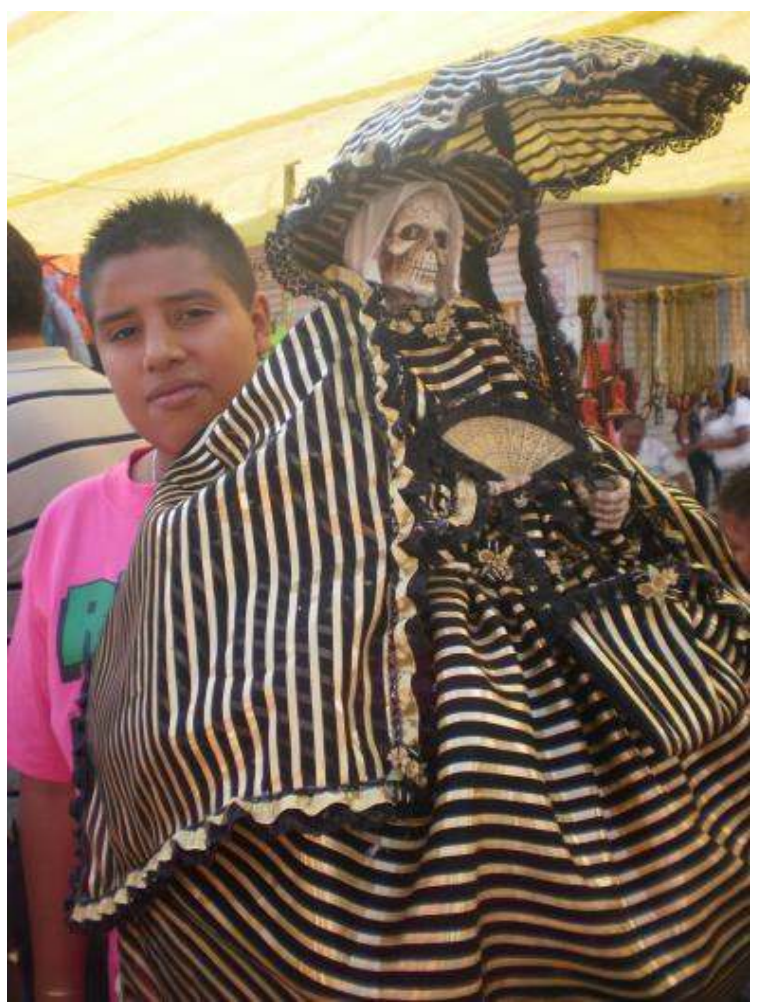

De esa manera, no es imposible que la costumbre de recubrir las imágenes del Niño Dios o de la Santa Muerte con ropas tornasoladas y ornamentos que puedan estimular profundamente los sentidos se corresponda con la tentativa de revivificar la facultad de acción sobre el mundo, facultad asociada a las divinidades pero susceptible de ser realzada por los mismos humanos a través de la virtud del rito. Los atuendos con los que se recubre al santo o a un individuo que reproduce sus rasgos (como en la celebración de San Judas Tadeo) exhibiría, en definitiva, en forma tangible y material, la función activa asociada al control del mundo a la que no es extraña la obra humana. Esa "espectacularización" de la vestimenta como vehículo de eficacia probablemente haya que relacionarla también con la gran importancia que la cultura popular acuerda a la dimensión sensorial, requerida en toda ocasión litúrgica, canónica o extracanónica. El impacto visual de los colores, de las formas, de los ornamentos y de los tejidos empleados produce fácilmente, incluso en el espectador "externo", una especie de estupefacción "estético-extática", que juega un rol nada secundario en la dinámica transformacional del ritual. Esto se evidencia claramente sobre todo en ocasión de las celebraciones durante las cuales los efectos cenestésicos engendrados por la convergencia de poderosos estímulos visuales, olfativos, sonoros y gustativos (combinados con condiciones físicas extremas) devienen palpables, como por ejemplo en los largos peregrinajes fuera del Distrito Federal, o durante los recitados de rosarios colectivos frente a los altares de la Santa Muerte, o incluso durante las procesiones extenuantes en honor del santo. 


\section{Reparaciones, estados hipnóticos y poder ortopráctico del ritual}

La investigación desarrollada en el Distrito Federal sobre la práctica consistente en vestir los santos puso en evidencia otro elemento: la omnipresencia, en la capital mexicana, de una infraestructura e innumerables actividades vinculadas a una reparación, a una restauración, como consecuencia de los estragos a los que toda persona, sin diferenciación, se encuentra expuesta, y a los que se encuentra expuesta también cualquier otra cosa, como instrumentos de trabajo, vestimentas, edificios, vehículos, electrodomésticos. Ciudad en obra, sin cesar movilizada en tareas de intervención en materia de roturas, averías, disfuncionamientos materiales e inmateriales, México exhibe los rasgos de una megalópolis "en trabajo" permanente. A ello hay que agregar la presencia frecuente de enfermeras que toman la presión en los pasillos del subterráneo, los centenares de gabinetes médicos y odontológicos improvisados, las farmacias "a cielo abierto"; los innumerables talleres mecánicos, de carrocerías, de electricidad, de carpintería, de tapicería, revendedores de piezas sueltas, los garajes y los sótanos transformados en talleres de vulcanización de neumáticos o de reparación de computadoras viejas, de aparatos de radio, de televisión, de máquinas de coser o cocinas, de automóviles y de camiones accidentados o arruinados; las costureras a domicilio; los talleres que practican retoques y zurcidos; los santeros y los magos. Así comenzó a confirmarse la impresión de que esta "puesta en escena de la función reparadora" -cuyos rasgos están encarnados por la Virgen de Guadalupe, San Judas Tadeo, la Santa Muerte, el Niño Dios y muchos otros santos populares-se encontraba de algún modo en relación con la práctica de vestir las imágenes sagradas (y más generalmente con recurrir a la vestimenta, concebida como el vehículo de una eficacia activa). Finalmente, una nueva relación de tres términos se imponía a la atención del investigador: la relación entre el estatus que ocupa la percepción visual en las prácticas rituales populares, los estados de sugestión extáticos y el hábito ceremonial, entendido como un poderoso estimulante sensorial, inductor de procesos autohipnóticos que facilitan la autorreparación de sí que el ritual promueve. 
Imagen del Campamento de Linda Vista

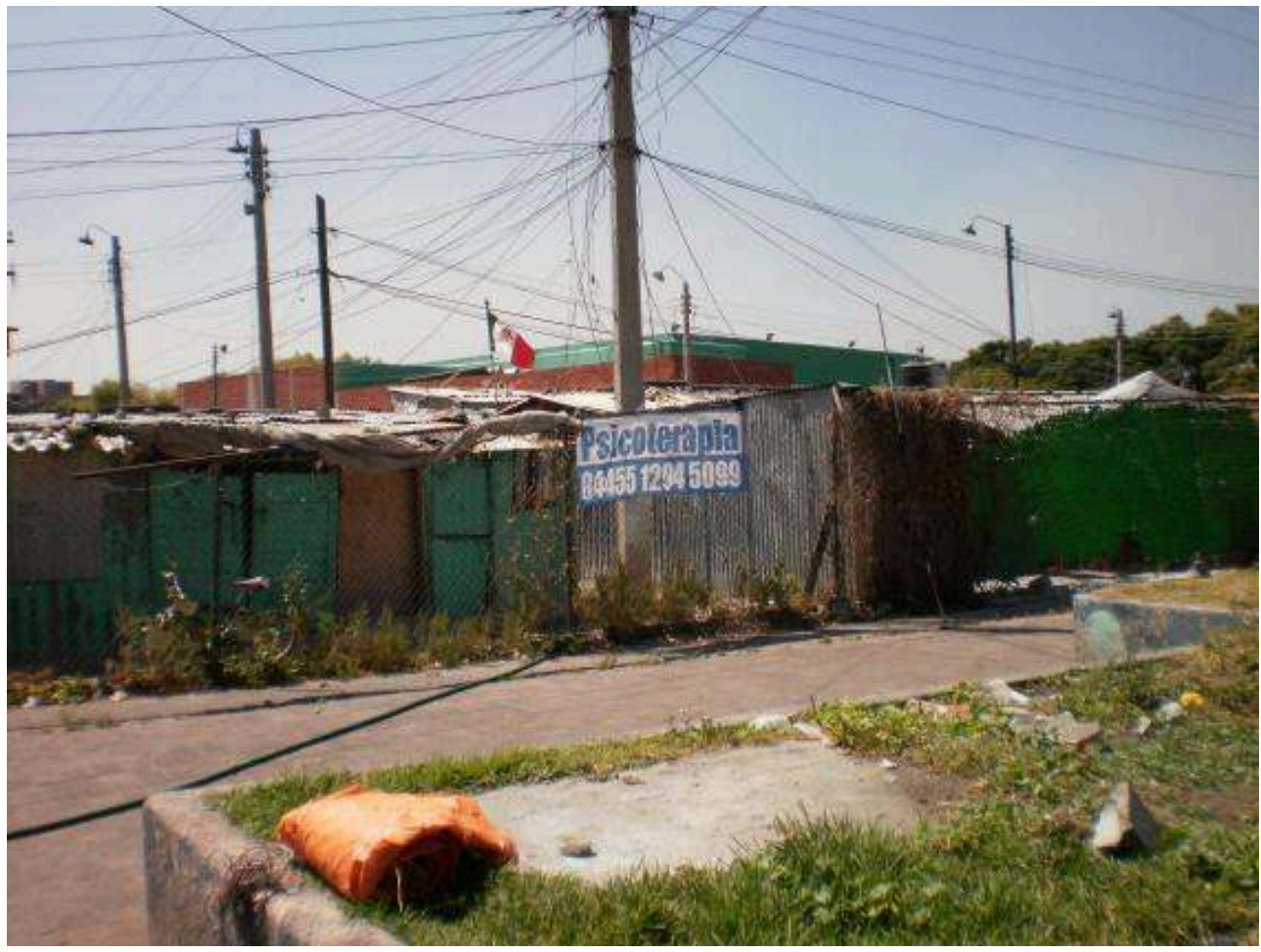

Diferentes medidas de prendas para el Niño cirujano y el Niño Doctor

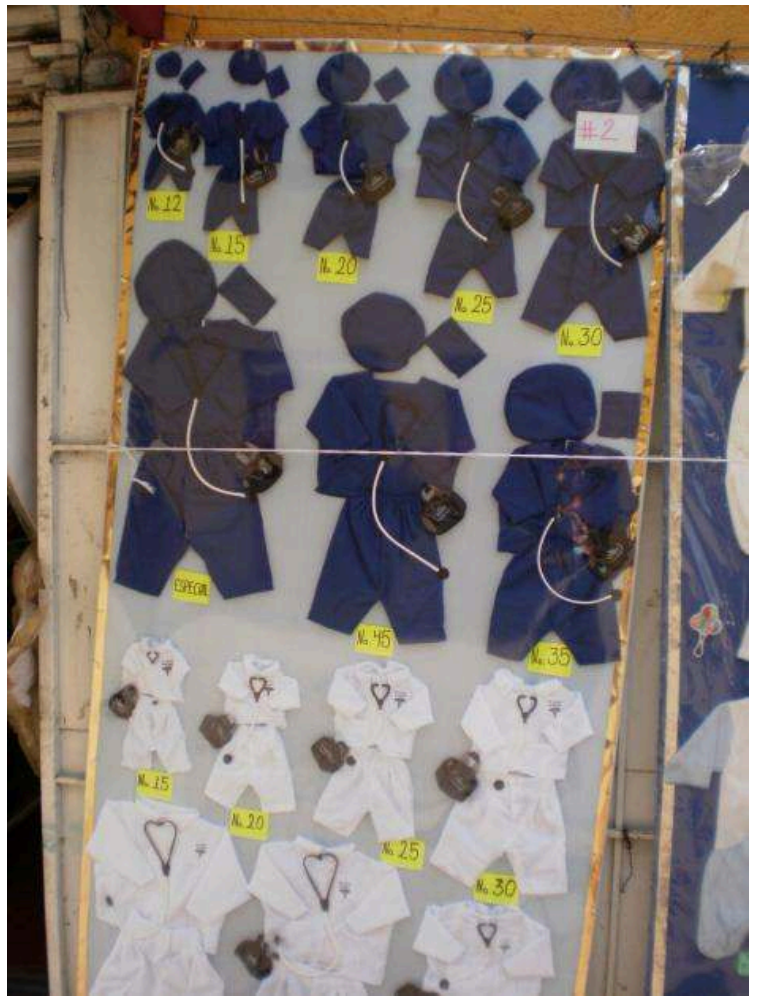

Las anteriores investigaciones realizadas en México habían comenzado con un interrogante sobre el uso institucionalizado de los estados psíquicos disociados, considerados un componente esencial de ciertas ortoprácticas locales, de naturaleza 
tanto "religiosa" como "civil". No es un hecho novedoso que en México los modi operandi que emplean los estados de sugestión (como en el caso de las prácticas chamánicas, de ciertas técnicas adivinatorias o terapéuticas tradicionales, cuyas raíces se remontan a la época prehispánica) hayan sido parcialmente reabsorbidos en formas devocionales cristianas y en prácticas seculares, con vocación edificante o pedagógica. El encuentro, en el año 2008, en la Colonia Moctezuma, con un culto espiritualista no institucionalizado nos llevó a una doble constatación. En primer lugar, el recurso a los estados extáticos con fines oraculares, protectores o reparadores no constituye la propiedad exclusiva de grupos étnicos rurales, sino que actúa también en la capital federal donde hay muchos "chamanes urbanos" que recurren a esos estados con el objetivo de repararse a sí mismos, o de reparar sistemáticamente el cuerpo y el espíritu de las personas que los consultan, golpeadas por los males de la modernidad. En segundo lugar, en las prácticas rituales con vocación correctiva el hábito y los accesorios de la vestimenta juegan un rol nada despreciable (Mancini, 2011).

En la periferia de México, un "Hospital de carburadores" prueba de un imaginario alrededor de la reparación y de la curación reintegradora

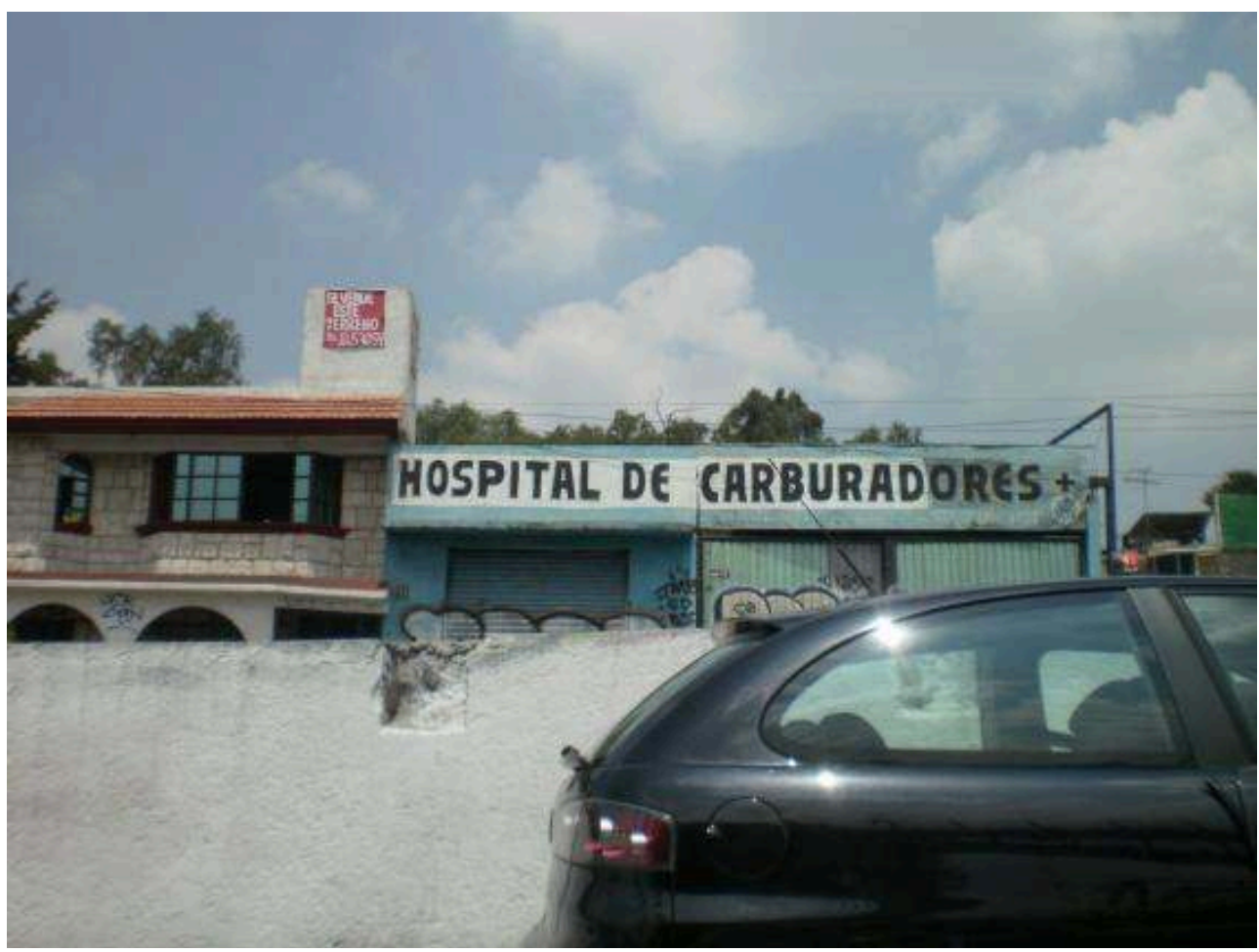

La observación, en el marco de esta investigación, del modo operatorio de algunas sesiones de adivinación y de cuidados terapéuticos, tanto en lugares de culto públicos como en espacios reducidos a una simple práctica intrafamiliar, había puesto en evidencia, en efecto, un dato interesante. Durante el desarrollo de la ficción ritual, el ejercicio de la función correctiva administrada por los operadores (generalmente individuos con características de médium-sanador) implicaba sistemáticamente una modificación de los roles y de las identidades normalmente atribuidas a los individuos implicados por la cura (ya se tratara del operador-sanador, de sus asistentes, de la persona que consultaba o del público). Este juego de roles y de identidades, prolongándose durante el tiempo necesario para la ejecución de la práctica reparadora, empleaba metódicamente las figuras del mimetismo y del desdoblamiento, que se 
tornaban explícitas tanto a través de las modificaciones de vestimenta de los operadores rituales como por el recurso a expedientes visuales específicos. Estos últimos reenviaban todos, infaliblemente, al universo de la reparación (imágenes de santos protectores, alusión al mundo médico-sanitario, representado con el uso de blusas blancas, "bálsamos", abluciones repetidas).Todos estos expedientes precipitan el proceso de reconstrucción de sí, en la medida en que, en la escenografía que actúa como telón de fondo de la cura, cada elemento vehiculiza sugestiones autopoiéticas o etho-poiéticas de fuerte impacto visual y emotivo (Borch-Jacobsen). Todo sucede como si, durante la liturgia terapéutica, los cambios de vestimenta y de rol favorecieran, en la asistencia, la emergencia de un nuevo punto de vista, que permitiría a las personas de esta asistencia verse actuar desde el exterior en posición de espectador, como si contemplaran a distancia una escena involucrando a otros individuos. Es gracias a este "descentramiento" o "desdoblamiento estratégico" -y gracias a la fuerte movilización sensorial actuante en esta dramaturgia compleja-que se activa el proceso de reprogramación de sí (Mancini, 2011).En el rito en acción, ni la entidad mítica convocada (en el caso estudiado en ese momento se trataba de tres entidades distintas, especie de espíritus ayudantes del médium-sanador), ni el atuendo utilizado por los operadores rituales que hacía alusión al universo médico se reducían a "símbolos" de algo. Tanto esas entidades como el atuendo parecían más bien vectores de acción, "artificios técnicos" susceptibles de promover y catalizar esta fuerza eficaz que pugna por actuar. Anticipando y haciendo presente, durante la cura, una situación crítica en vías de ser resuelta, el llamamiento a la entidad extrahumana protectora y la medicalización de la escenografía funcionan, en definitiva, como "inductores" que obligan a los presentes a tomarse de la mano, a proceder a una rectificación de su conducta, ya que su postura anterior evidenciaba ser una "mala postura" (Latour, 2009).

25 A diferencia de los cultos neoespiritualistas urbanos, institucionalizados o no, donde la referencia al universo médico-sanitario es omnipresente (el recurso metódico a los uniformes blancos y a las abluciones son su marca más evidente), en el caso del culto a la Santa Muerte la relación entre los estados de sugestión, el proceso de autorreparación y los hábitos rituales se activa en dos niveles distintos. El de la fabricación de la vestimenta de la imagen, realizada por costureras especializadas; el del acto ceremonial de vestir esta misma imagen, en el marco de los festejos organizados por su aniversario, que coincide con el ofrecimiento a la Santa de un nuevo vestido de parte del dueño del altar. En un primer nivel, la observación etnográfica permitió constatar que un estado ligeramente autohipnótico se apodera efectivamente de la artesana en acción. El modo operatorio del proceso de confección y de terminación de los vestidos destinados a la imagen parece en efecto favorecer en ella la emergencia de un fenómeno de disociación psíquica parcial (Latry, 2002). Tarea repetitiva y automática, que implica una gran concentración y la capacidad de adaptar el trabajo de costura a las proporciones poco comunes de esta extraña "clienta" que es la Santa, la fabricación de sus vestidos se efectúa en los talleres domésticos de las costureras. Devotas ellas mismas, protagonistas de una historia de vida donde la experiencia de la prostitución, las desgracias familiares y la droga constituyen ingredientes reiterados, estas mujeres viven en apartamentos minúsculos, en inmuebles populares o en viviendas de chapa “provisorias", entregadas por el Estado después del terremoto de 1980. Sus habilidades y competencias para cortar y coser fueron adquiridas a veces durante su detención en los reclusorios femeninos del Distrito Federal. En los pequeños locales de esos 
apartamentos o viviendas-taller, proliferan las referencias simbólicas a la Flaquita (imágenes, oraciones impresas, montañas de tejidos destinados a su ajuar, fotos de altares, números de la revista Santa Muerte mostrando nuevos modelos de vestido, etcétera). Durante las sesiones de trabajo, la atención focalizada en el trabajo pendiente, el movimiento repetitivo de la máquina de coser, los comentarios en voz alta que acompañan la elección de la línea, del tejido, del color, de las terminaciones y de los accesorios combinados destinados a completar el vestido de la estatuilla, tratada como si se tratara de una persona de carne y hueso, todo contribuye a borronear la barrera que separa el régimen de realidad de la Santa, y el de la costurera en su trabajo. No es casual que durante su trabajo las costureras afirmen "escuchar" y "ver" a la Santa en la pieza. A esta presencia se dirigen como a una clienta, y a medida que el trabajo avanza (por ejemplo, durante las pruebas) se confirman sus gustos, se indaga sobre los estados de ánimo y las expresiones de su "rostro", para descifrar los signos de su aprobación o de su desaprobación con respecto a las decisiones de estilo adoptadas.

En otro nivel, los procesos de sugestión se activan durante la celebración colectiva del aniversario de la efigie, en el momento de renovar su vestimenta y sus accesorios (o de vestir por primera vez la imagen en ocasión de la inauguración de su altar). La porosidad psíquica que se instala en los devotos en esas circunstancias festivas no es un hecho exclusivo del contexto ritual, que facilita la "simultaneización" de dos regímenes de existencia diferentes (aquel al que pertenecen los fieles y el de su protectora extrahumana). La fluidez-porosidad psíquica, favorecida por la experiencia de una promiscuidad excepcional con la Niña Blanca, promiscuidad amplificada por el acto íntimo que representa su cambio de vestimenta, se encuentra en efecto desmultiplicado durante la fiesta por el recurso a estimulantes poderosos, tales como alcohol (pulque, cerveza, tequila), mota (marihuana) o drogas incluso más intensas (por ejemplo, entre los jóvenes, la piedra o el pegamento, una y otro de base química).

Desde hace ya un tiempo, la hipnosis moderna ha puesto en evidencia cómo el trabajo de redefinición de las posturas existenciales y comportamentales de los sujetos "mal posicionados" es susceptible de extraer beneficios del recurso estratégico o "utilizacional" de los estados psíquicos disociados, al igual que sucede en el trabajo de "reposicionamiento" del sujeto realizado en el marco de la inducción hipnótica artificial (Melchior, 1998: 126). Por su lado, la antropología ha subrayado en múltiples ocasiones que la música, el alcohol, las drogas, la danza y otras técnicas del cuerpo inductoras de una disociación psíquica parcial ofrecen un soporte propicio para ciertas ortoprácticas que activan dispositivos simbólicos ad hoc, destinados a "reprogramar" las conductas, a facilitar la memorización de nuevos esquemas de comportamiento, tanto individuales como colectivos. La renovación de la vestimenta de la imagen de la Santa Muerte es realizada con gran pompa y con un despliegue de medios económicos y de artificios escenográficos excepcionales, como la compra de decoraciones coloreadas y resplandecientes, velas e incienso, drogas, alimentos y bebidas, pero también, cuando es posible, se reclutan costosos grupos de mariachis y de danzantes. Así el acto de volver a vestir la imagen parece cumplir dos funciones diferentes. Por un lado, permite una humanización-identificación más radical del devoto con su entidad protectora, que funciona, como hemos visto, como una "prótesis" de sí. Por el otro, la "espectacularización" de la dependencia del dueño con respecto a la imagen sagrada, que él viste y alimenta al precio de grandes sacrificios (el pedido de trabajo a una costurera alcanza veces los 3.000 o 4.000 pesos), permite al devoto intervenir desde el exterior sobre sí mismo. Lo hace sirviéndose de un dispositivo simbólico (la Santa) que, 
bajo una forma personificada, externaliza su propia capacidad de autocorrección y de autoprogramación en función de una reapertura hacia la acción.

\section{Conclusión}

En 1982 Marc Augé recordaba que el paganismo, en sus diversas modalidades, se distingue radicalmente del cristianismo al menos en tres puntos:

1) "primero, nunca es dualista y no opone ni el espíritu al cuerpo ni la fe al saber; 2) no constituye a la moral como un principio exterior a las relaciones de fuerzas y de sentidos que traducen los azares de la vida individual y social. Postula una continuidad entre orden biológico y orden social [...]; 3) La salvación, la trascendencia y el misterio le son extraños. Por consiguiente, recibe la novedad con interés y espíritu de tolerancia; siempre dispuesto a alargar la lista de dioses, concibe la adición, la alternancia, pero no la síntesis. Ésa es ciertamente la razón más profunda y más duradera de su malentendido con el proselitismo cristiano: de su parte jamás ha habido una práctica misional" (Augé, 1982: 14)

Si la figura de la Santa Muerte comparte con las divinidades paganas esta proximidad con los humanos, otorgándole el derecho de intervenir y de corregir su suerte por medio del rito, es precisamente porque la realidad cotidiana necesita hoy, en México, este trabajo constante de control, de reparación, de exorcismo del miedo; en suma, la humanización de un mundo experimentado como no humano. La vida en el Valle de México torna difícil, entonces, la hipótesis según la cual este nuevo "santo" del panteón popular mexicano sería la supervivencia de un antiguo substrato cultural politeísta, que se remontaría a la época precolonial y a la estética de la muerte, cuya culminación ideal estaría encarnada por los aztecas, con sus sacrificios sangrientos. La razón de ser del culto de la Santa Muerte tampoco parece susceptible de ser relacionada con un efecto secundario de la idea franciscana de la muerte en tanto hermana-idea difundida por la predicación misional durante la primera ola de evangelización en México-, ni a un efecto de la cultura barroca española, que hizo del principio del memento mori un leit-motiv de su poética.

Así como los paganismos antiguos o los de los pueblos primeros no se tornan accesibles a la comprensión más que a través de un conocimiento global del biotopo cultural y del medio ambiente que los engendró y en el cual prosperan, así la ecología del culto de la Santa Muerte adquiere todo su sentido en la coyuntura histórica que México está viviendo aquí y ahora: un país de frontera cuya catástrofe medioambiental y cultural comenzó el día en que los conquistadores se apropiaron de Tenochtitlan.

BIBLIOGRAFÍA

\section{Créditos}

Las fotos sin mención son de Silvia MANCINI. 
Dirección: IRCM -FTSR Université de Lausanne Anthropole - bureau 5016 UNIL, Dorigny, 1015 Lausanne CH Email: silvia.mancini@unil.ch

Las fotos con mención pertenecen a Francis MOBIO Dirección: IRCM -FTSR Université de Lausanne Anthropole - bureau 5016 UNIL, Dorigny, 1015 Lausanne CH Email: francis.mobio@unil.ch

\section{Bibliografía}

ASSMANN, Jan (2007), Le prix du monothéisme, Flammarion, París.

AUGE, Marc (1982), Génie du paganisme, Gallimard, París.

AUSTIN López, Alfredo (1996), Cuerpo humano e ideología. Las concepciones de los antiguos nahuas, vol. I y II, México, UNAM (“Antropológica”).

AUSTIN López, Alfredo (1998), Hombre-dios: religión y política en el mundo náhuatl, México, Instituto de Investigaciones Históricas, UNAM.

BÁEZ CUBERO, Lourdes (2010), “Para vestir 'santos': el acto ritual de vestir a las deidades entre otomíes y nahuas de la Sierra Madre oriental”, comunicación presentada al congreso internacional Simbolismo y ritual en el textil mesoamericano, Oaxaca, 13 al 15 de octubre de 2010.

BERNAND, Carmen y Serge GRUZINSKI (1988), De l'Idolâtrie. Une archéologie des sciences religieuses, Seuil, París.

BORCH-JACOBSEN, Mikkel (1993), “L'efficacité mimétique”, en Daniel Bougnoux (ed.), La suggestion. Hypnose, influence, transe (Coloquio de Cerisy-la-Salle), Delagrange ("Les Empêcheurs de penser en rond"), París.

DEHOUVE, Danièle (2010), “De mantas y manchas entre los tlapanecos de Guerrero", comunicación presentada al congreso internacional Simbolismo y ritual en el textil mesoamericano, Oaxaca, 13 al 15 de octubre de 2010.

DE LA TORRE, Renée (2008), "La estetización y los usos culturales de la danza conchera-azteca”, en Raíces en movimiento. Prácticas religiosas tradicionales en contextos translocales, México, CEMCA-IRD, CIESAS-Occidente, 73-110.

DE MARTINO, Ernesto (1958), Morte e pianto rituale. Del lamento funebre al pianto di Maria, Boringhieri, Turín.

DESCOLA, Philippe (2005), Par delà nature et culture, Gallimard, París. Galinier, J. y A. Molinié (2006), Les néo-indiens. Une religion du IIIème Millènaire, Odile Jacob, París.

GARCIA Ruiz, Jesús (2008), “Acteurs locaux, acteurs globaux: les néo-pentecôtistes en Amérique latine”, L’Homme, no 185-186, número especial: L'Anthropologie et le contemporain: autour de Marc Augé, enero-junio, 387-400.

GRUZINSKI, Serge (1999), La pensée métissée, Fayard, París.

GRUZINSKI, Serge (1990), La guerre des images. De Christophe Colomb à Blade Runner (1492-2019), París, Fayard.

GRUZINSKI, Serge (1992), "La permeabilité des mondes. Rêves et visions dans le Mexique ancien”, en Serge Gruzinski, Antoinette Molinié-Fioravanti, Carmen Salazar y Jean-Michel Sallmann, Visions indiennes, visions baroques: le métissage de l'inconscient, París, PUF. 
LATOUR, Bruno (2009), Sur le culte moderne des dieux faitiches, París, La Découverte ("Les Empêcheurs de penser en rond").

LATRY, Marie-Claire (2002), Le fil du rêve. Des couturières entre les vivants et les morts, París, L'Harmattan (“Anthropologie du monde occidental”).

LEÓN-PORTILLA, Miguel (1958), Sacerdotes y atavíos de los Dioses, UNAM, México.

MALVIDO, Elsa (2006), “Crónicas de la Buena Muerte a la Santa Muerte”, Arqueología Mexicana, v. XIII, nº 76, enero 2006, México.

MANCINI, Silvia (2011), “Les Hermanitos d'Eusebio, ou la personnification 'faitiche' dans un cas de spiritualisme non-institutionnalisé de Mexico City", en Techniques de l'esprit et du corps dans les deux Amériques, París, Imago (en prensa).

MANCINI, Silvia (2010), “La Santa Muerte e la storia delle religioni”, en F. Mobio, Santa Muerte. Mexico, la Mort et ses dévots, París, Imago, 153-164.

MANCINI, Silvia (2008), "Par delà magie et psychothérapie. L'efficacité de la 'deshistorisation' mythico-rituelle”, en Edouard Collot (ed.), Hypnose et pensée magique, París, Imago, 51-72.

MELCHIOR, Thierry (1998), Créer le réel. Hypnose et thérapie, París, Seuil.

MOBIO, Francis (2010), Santa Muerte. Mexico, la Mort et ses dévots, Paris, Imago.

STRESSER Pean, Claude (2011), Des vêtements et des hommes. Une perspective historique du vêtement indigène au Mexique, París, Riveneuve.

\section{NOTAS}

1. Diminutivo afectuoso con el que los devotos designan a la Santa Muerte, representada como un esqueleto vestido.

2. Término que designa a los habitantes del Distrito Federal, cuya capital es la ciudad de México, caracterizados por una manera particular de hablar, combinado con un comportamiento extrovertido y cierta soberbia machista.

3. Según la costumbre latinoamericana, las adolescentes, rodeadas de su familia y susamigos, festejan con gran pompa su decimoquinto aniversario, concebido como una etapa existencial y social importante (a partir de ese momento, ella puede noviar o casarse). Esta celebración exige un atuendo especial, cuyo estilo se sitúa entre el vestido de fiesta y el de casamiento.

4. Acrónimo del Centro de Detención Reclusorio Norte, en el Distrito Federal.

5. Esta noción debe ser entendida como "comunidad de esencia bajo formas cambiantes" (Gruzinski, La pensée... 1999: 264-266, y S. Gruzinski y C. Bernand, De l'idolatrie..., 1988: 101-104). Sobre este tema, cf. también S. Gruzinski, A. Fioravanti, C. Salazar y J.M. Sallmann, Visions indiennes, 1992: 54-55.

6. Este proyecto, financiado por el Fondo Nacional Suizo para la Investigación -y realizado gracias a los medios logísticos y documentales puestos a disposición por el CEMCA (UMIFRE n. 16 - USR 3337 del CNRS) de México-, tiene como título “Vestimenta y 'eficacia' ritual. Investigación sobre el estatus de la función de la vestimenta en las prácticas taumatúrgicas y transformacionales actuantes en la religiosidad popular del México central". 


\section{RESÚMENES}

El origen y la difusión del culto de la Santa Muerte, que se está propagando en México de manera exponencial, suscitó las interpretaciones más diversas: herencia del mundo precolonial; iconografía de la "hermana Muerte" promovida por los franciscanos, evangelizadores de México; estética barroca; rehabilitación antirreligiosa y polémica, a comienzos del siglo XX, de un culto precolombino. Cada una de estas interpretaciones constituye una lectura diferente convocada consecutivamente para dar cuenta de esta institución. Si bien todas estas formas de abordaje son legítimas, sin embargo no son incompatibles con el cuestionamiento sobre la ecología de este culto. A partir de la hipótesis de una co-génesis y de un co-desarrollo de esta práctica devocional con la catástrofe medioambiental que ha impactado al valle de México, este artículo quiere explorar la lógica de las prácticas que rodean a la Santa Muerte, especie de prtótesis simbólica por la cual los adeptos prolongan su dominio sobre el mundo y se adaptan a él.

L'origine et la diffusion du culte de la Santa Muerte, en train de se propager au Mexique de manière exponentielle, a suscité les interprétations les plus diverses: l'héritage du monde précolonial; l'iconographie de la 'sœur Mort' promue par les franciscains; l'esthétique baroque; la réhabilitation antireligieuse et polémique, au début du XXème siècle, d'un culte précolombien constituent autant de lectures convoquées tour à tour pour rendre compte de cette institution. Si toutes ces interrogations sont légitimes elles ne sont pas pour autant incompatibles avec le questionnement sur l'écologie de ce culte. A partir de l'hypothèse d'une co-genèse et d'un codéveloppement de cette pratique dévotionnelle avec la catastrophe environnementale qui a frappé la vallée de Mexico, cet article veux explorer la logique des pratiques entourant la Santa sorte de prothèse symbolique par laquelle les adeptes prolongent leur emprise sur le monde et s'adaptent à lui.

\section{ÍNDICE}

Palabras claves: Santa Muerte, México, politeísmo, estados psiquicos disociados, vestidos rituales

\section{AUTOR}

\section{SILVIA MANCINI}

Profesora de Historia comparada de las religiones en la Universidad de Lausana (Suiza) 